\title{
Bloody Nipple Discharge in Infants
}

\section{Bebeklerde Meme Başından Kanlı Akıntı}

\author{
Nalan Karabayır ${ }^{1}(\mathbb{D})$, Abdulkadir Eren ${ }^{2}$ (D), Gülçin Canbeyli ${ }^{3}(\mathbb{C}$ \\ ${ }^{1}$ Istanbul Medipol University, International Faculty of Medicine, Department of Pediatrics, Istanbul, Turkey \\ ${ }^{2}$ Istanbul Medipol University, Department of Radiology, Istanbul, Turkey \\ ${ }^{3}$ Istanbul Medipol University, International Faculty of Medicine, Istanbul, Turkey
}

ORCID ID: N.K. 0000-0002-8003-1952; A.E. 0000-0003-0958-6581; G.C. 0000-0003-2070-7014

Citation/Atff: Karabayir N, Eren A, Canbeyli G. Bloody nipple discharge in infants. Çocuk Dergisi - Journal of Child 2020;20(1):40-42. https://doi.org/10.26650/jchild.2020.1.0008

ABSTRACT

Bloody nipple discharge is extremely rare in children. The etiology and pathophysiology remain uncertain, with the most common cause being mammary ductal ectasia. Despite its stressful course to the parents, it is generally a benign condition with a spontaneous resolution. A 3-monthold and a 6-month-old female infants were admitted to our clinic because of bloody discharge from the nipples. Bilateral fibrocystic changes were detected in the ultrasonographic examination of the infants, whose physical examination and hemogram, prothrombin time, aPTT, estradiol levels were normal. The hemorrhage ended within one month in the follow-up of both cases, but in our 6-month-old patient, bleeding recurred once again after 10 months. As a conclusion, in cases of bloody nipple discharge, which is seen rarely during infancy, the bleeding usually disappears spontaneously without any intervention. After detailed evaluation of the cases, they should be followed conservatively.

Keywords: Bleeding, ductal ectasia, infant, nipple discharge öz

Çocuklarda meme ucu kanlı akıntısı çok nadir görülmekte olup, etyolojisi ve patofizyolojisi bilinmemektedir. En sık neden duktal ektazidir. Ebeveynleri endişelendirmesine rağmen sıklıkla spontan olarak gerileyen selim bir durumdur. Memeden kanlı akıntı nedeniyle kliniğimize başvuran 3 ve 6 aylık iki kız bebeğin yapılan fizik muayenelerinde özellik saptanmadı. Hemogram, aPTT, prothrombin zamanı ve estradiol değerleri normal bulunan olguların yapılan ultrasonografilerinde duktal ektaziye bağlı bilateral fibrokistik değişiklikler görüldü. Her iki olgunun takibinde kanamaların bir ay içinde kaybolduğu saptanırken, 6 aylık olan olgumuzda 10 ay sonra bir kez daha kanama tekrar etti. Sonuç olarak sıklıkla duktal ektazi sonucu gelişen meme ucu kanlı akıntısında kanama, tedaviye gerek kalmadan kendiliğinden kaybolmaktadır. Olgular detaylı bir şekilde değerlendirildikten sonra konservatif olarak takip edilmelidir.

Anahtar Kelimeler: Çocuk, duktal ektazi, kanama, meme ucu akıntısı

\section{INTRODUCTION}

Bloody nipple discharge (BND) in children is extremely rare, and presents a challenge for the management of nipple discharge in children. Despite its etiology and pathophysiology remaining unclear, it is generally a benign condition with a spontaneous resolution (1). The most common cause in children is mammary duct ectasia, which is a benign and selflimiting condition. Up to date, only isolated case reports have been published. The approach to bloody nipple discharge in the infantile period is well documented in the literature, even though the number of these cases is limited (2). In this article, 2 female children presented with bleeding from the nipples were reported.

\section{CASE}

Case 1: A six-month-old female child who was examined for having bleeding in the breast nipples bilaterally did not have any other pathological findings. Hemogram, prothrombin time: $12.2 \mathrm{sec}$, aPTT: $31.6 \mathrm{sec}$, prolactin: $14.71 \mathrm{ng} / \mathrm{mL}$ [normal 4.2$20.2 \mathrm{ng} / \mathrm{mL}$ ] and estradiol: $<5.00 \mathrm{pg} / \mathrm{mL}$ [normal $<22 \mathrm{pg} / \mathrm{mL}$ ] levels were revealed as normal. There were bilateral fibrocystic changes found in the mammary ultrasonography of the child who did not have any trauma in her history (Figure 1). The fibrocysts were $6.5 \times 4.2 \mathrm{~mm}$ on the right breast and $9.6 \times 3.6 \mathrm{~mm}$ on the left breast. The bleeding disappeared in the following 2 months. The patient, who had bleeding once again after 10 months, is still being followed without any problem. 


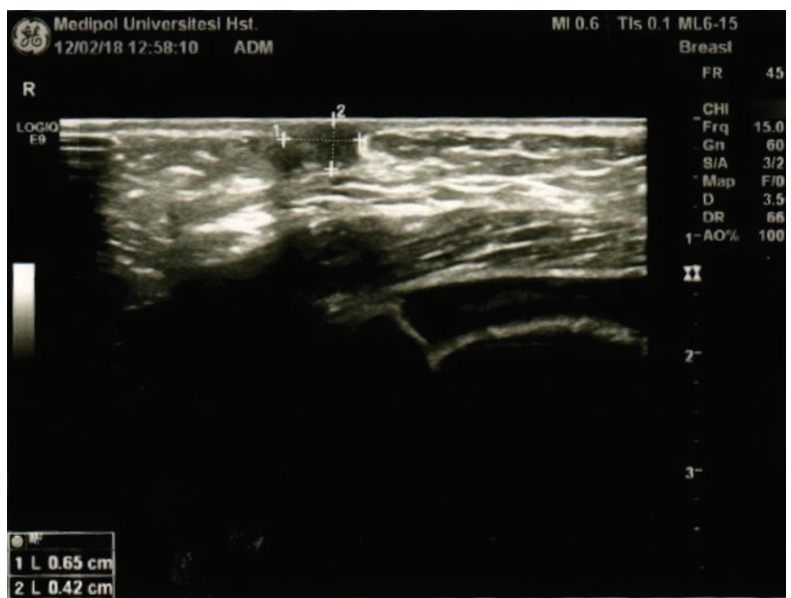

Figure 1: Breast ultrasonography of the case 1 showing retroareolar dilated ducts

Case 2: A three-month-old female child who was examined for having a hemorrhage in the right breast did not have any other pathological finding. Hemogram, prothrombin time: $12.6 \mathrm{sec}$, aPTT: 34.1 , prolactin and estradiol: $<5.00 \mathrm{pg} / \mathrm{mL}$ levels were evaluated as normal. There were bilateral fibrocystic changes found in the mammary ultrasonography of the child, who did not have any trauma in her history. The fibrocysts were $15.8 \times 6.3 \mathrm{~mm}$ on the right breast and $13.7 \times 4 \mathrm{~mm}$ on the left breast. In the following month, the hemorrhage in the breast tissue disappeared spontaneously.

\section{DISCUSSION}

Bloodstained nipple discharge is an extremely uncommon but distressing finding in children. Although milky nipple discharge is frequently seen in neonates and infants, usually associated with a palpable breast enlargement, bloody nipple discharge is rarely seen in children $(3,4)$. The underlying pathology of BND differs by age group. In adulthood, BND is associated with benign pathologies, such as intraductal papilloma, mammary ductal ectasia (MDE), and breast nodularity, as well as malignant pathology, such as invasive or intraductal carcinoma $(4,5)$. Possible causes of bloody nipple discharge in children include benign conditions such as an abnormal response of the breast tissue to maternal hormones, high levels of progesterone, MDE, intraductal papilloma, intraductal cyst or mammary ductal hyperplasia. In children, bloody nipple discharge is most often caused by MDE (6). The pathogenesis and etiology of mammary ductal ectasia with bloody nipple discharge are unclear. There have been some reports of bacterial overgrowth in the nipple discharge (7). There were no infections or endocrine disorders in our cases. Bloody nipple discharge often occurs in children under 4 years of age. While there is a male predominance in an under-aged child, both genders are seen at equal frequency in children over 1 year (8). Mendez-Gallart et al, reported a 9 years old male patient with ductal ectasia and a persistent palpable breast mass (3). Our female cases were also under 1 year old. The typical clinical presentation in children includes intermittent unilateral or bilateral BND, without any inflammatory signs, and with or without associated breast hypertrophy or palpable mass (5). The ultrasonographic findings of mammary duct ectasia include tubular anechoic structures or dilated ducts filled with debris. The cystic lesions may be small and simple, or larger and multiseptated or complex (9-12). Moon et al. reported 3 cases of mammary duct ectasia in infancy and childhood, with variable imaging findings, including complex cystic and solid lesions (13). Bilateral ductal dilatations were detected on ultrasonography in our two cases. Duct ectasia accompanied by BND is a selflimiting condition occurring in the neonatal and childhood periods. Criteria for surgery include suspicious cytological results, lesions that continue to bleed, ultrasonographic findings of a mass or abnormality other than MDE, lesions that expand in size, presence of pain or tenderness, and BND that does not resolve within 9 months $(14,15)$. Forty six cases reported in a review of children with BND showed that symptoms are caused by benign, self-limiting disorders, mostly MDE. BND is likely to resolve spontaneously within 10 months (6). Bleeding was reported in one of our cases after 10 months. Invasive interventions including biopsy should be avoided, especially in girls, because even minimal operative injury to the breast bud may produce severe tissue damage. Noninvasive investigations such as culture of the discharge and ultrasonographic evaluation are recommended, as well as a careful physical examination and close clinical follow-up (16). As a conclusion, bloody nipple discharge is a benign, self-limiting disorder in young children. Ultrasonography is the most important diagnostic tool in these cases, and unnecessary interventions should be avoided when spontaneous healing is observed.

Peer Review: Externally peer-reviewed.

Author Contributions: Data Acquisition- N.K.; Data Analysis/ Interpretation- A.E.; Drafting Manuscript- G.C.; Final Approval and Accountability- N.K., A.E., G.C.; Technical or Material Support- G.C.

Conflict of Interest: Authors declared no conflict of interest.

Financial Disclosure: Authors declared no financial support.

Hakem Değerlendirmesi: Dış bağımsız.

Yazar Katkıları: Veri Toplama- N.K.; Veri Analizi/Yorumlama- A.E.; Yazı Taslağı- G.C.; Son Onay ve Sorumluluk- N.K., A.E., G.C.; Malzeme ve Teknik Destek- G.C.

Çıkar Çatışması: Yazarlar çıkar çatışması beyan etmemişlerdir.

Finansal Destek: Yazarlar finansal destek beyan etmemişlerdir.

\section{REFERENCES}

1. De Praeter C, De Coen K, Vanneste K, Vanhaesebrouck P. Unilateral bloody nipple discharge in a two-month-old male. Eur J Pediatr 2008;167:457-9.

2. Pampal A, Gokoz A, Sipahi T, Dogan H, Ergur AT. Bloody nipple discharge in 2 infants with interesting cytologic findings of extramedullary hematopoiesis and hemophagocytosis. J Pediatr Hematol Oncol 2012;34:229-31. 
3. Méndez-Gallart R, García-Palacios M, Bautista-Casasnovas. Spontaneous brownish nipple discharge in a 9-year-old boy. Pediatr Dermatol 2017;34:361-2.

4. Jung Y, Chung JH. Mammary duct ectasia with bloody nipple discharge in a child. Ann Surg Treat Res 2014;86:165-7.

5. Trojanowska-Szostek M, Kulik-Rechberger B. Bloody nipple discharge in an 3,5-month-old boy. Pediatr Endocrinol Diabetes Metab 2013;20:30-2.

6. Leung AK, Kao CP. Mammary duct ectasia: a cause of bloody nipple discharge. J Natl Med Assoc 2004;96:543-5.

7. Kaplan R, Hoda SA, Hoda RS. Cytological evaluation of bloody nipple discharge fluid. Diagn Cytopathol 2013;41:183-5.

8. Acer T, Derbent M, Hiçsönmez A. Bloody nipple discharge as a benign, self-limiting disorder in young children: A systematic review including two related case reports. J Ped Surg 2015; 50:1975-82.

9. Gupta V, Yadav SK. Infantile bloody nipple discharge: a case report and review of the literature. Afr J Paediatr Surg 2009;6:63-4.

10. Paula IB, Campos AM. Breast imaging in patients with nipple discharge. Radiol Bras 2017;50(6):383-8.
11. Ascaso Matamata ÁM, Amiguet Biain M, Morales Ferruz R, Sobrevia Elfau MT, González García G. Duct ectasia, an infrequent condition in childhood: A case report. Arch Argent Pediatr 2018;116(6):782-4.

12. Bayrak IK, Yalin T, Nural MS, Ceyhan M. Mammary duct ectasia in infant breast with bloody nipple discharge: sonographic findings. J Clin Ultrasound 2008;36:229-30.

13. Moon S, Lim HS, Ki SY. Ultrasound findings of mammary duct ectasia causing bloody nipple discharge in infancy and childhood. J Ultrasound Med 38:2793-2798.

14. Zegpi MS, Downey C, Vial-Letelier V. Mammary duct ectasia in children: A case report. Rev Chil Pediatr 2015;86:287-90.

15. Aydın R, Gul SB, Polat AV. Detection of duct ectasia of mammary gland by ultrasonography in a neonate with bloody nipple discharge. Pediatr Neonatol 2014;55:228-30.

16. Harmsen S, Mayatepek E, Klee D, Meissner T. Bloody nipple discharge (BND) in an 8 month old girl and a 9 months old malerational diagnostic approach. Klin Padiatr 2010; 222:79-83. 